Received: November 5, 2017

\title{
"The Belt and Road" and Environmental Education for College Students before Overseas Study Tour*
}

\author{
Haibin Zhang ${ }^{1}$ \\ Zhejiang A \& F University
}

\author{
Chengjun Wang ${ }^{2}$ \\ Zhejiang A \& F University
}

\begin{abstract}
The original intention of the "the Belt and Road" strategy is to promote the economic development in countries and regions along the route through technological, capital, cultural and educational exchanges. However, the flow of infrastructure and personnel is bound to pose serious challenges to the ecological environment of the countries and regions along the route. Therefore, the research on how to strengthen the education of environmental awareness of mobile personnel is of great significance for promoting the smooth implementation of "the Belt and Road" strategy. Based on the popular phenomenon of short-term overseas study tour of college students in recent years, this paper conducts the association study of the environmental education for college students before overseas study tour and "the Belt and Road" strategy based on the overall analysis of the ecological environment status of the countries and regions along "the Belt and Road". The research results show that the pre-school environmental education has a positive impact on the smooth implementation of "the Belt and Road". The importance analysis and education content recommendations of environmental education for college students before overseas study tour in this paper is conducive to expanding the international influence of the "green development concept" advocated by China. Meanwhile, it is of great practical significance for the smooth implementation of "the Belt and Road" strategy.
\end{abstract}

\section{Keywords}

The Belt and Road $\bullet$ Environmental Protection $•$ Higher Education $\bullet$ Overseas Study Tour

\footnotetext{
This research was funded by Education Bureau of Zhejiang, No. Y201738026

${ }^{1}$ Zhejiang A \& F University, Economics and Management College, Hangzhou, 311300, China. Email: zhanghaibin18@zafu.edu.cn

2 Correspondence to: Chengjun Wang $(\mathrm{PhD})$, Zhejiang A \& F University, Economics and Management College, Hangzhou 311300. China. Email: $103950809 @ q q . c o m$
}

Citation: Zhang, H. B., \& Wang, C. J. (2018). "The Belt and Road" and Environmental Education for College Students before Overseas Study Tour. Educational Sciences: Theory \& Practice, 18(5), 2533-2539. http://dx.doi.org/10.12738/estp.2018.5.155 
"The Belt and Road" was originated from the "Silk Road Economic Belt" and "21st Century Maritime Silk Road" initiative proposed by Chinese President Xi Jinping in 2013. Once this initiative was proposed, it was quickly welcomed by countries and regions along "the Belt and Road" (Wang \& Zhang, 2016). In 2015, the Chinese government issued the "Vision and Action for Promoting the Construction of the Silk Road Economic Belt and the 21st Century Maritime Silk Road", officially upgrading "the Belt and Road" initiative to the national strategy in China. Subsequently, more than 70 countries quickly expressed their support and participation willingness for "the Belt and Road" strategy (Li, 2017). However, the flow of infrastructure and personnel brought by "the Belt and Road" strategy also poses three challenges to the environmental protection issue in countries and regions along the route: challenges in legal system, challenges in natural environment, and challenges in governance capacity (Bräutigam \& Tang, 2014; Khanji, 2017; Meir \& Alkon, 2018).

\section{Challenges in Legal System}

Studies have shown that the legislation perfection on environmental protection in countries and regions along the "the Belt and Road" is not the same. Also, even in the countries with legislation, there are significant differences in the legal system and legal procedure (Bräutigam \& Tang, 2014). For example, the legal system for environmental protection in developed countries in the Middle East and Europe is generally relatively complete and these countries have extremely high requirements for environmental protection standards. However, developing countries in Southeast Asia and Africa have low requirements for environmental protection standards and some countries even have not enacted laws on environmental protection. Therefore, how to establish a unified discourse system and build a reciprocal cooperation mechanism in the legal system among all parties is one of the most important challenges. The existing solution is mainly to carry out bilateral or multilateral cooperation in accordance with the legal provisions of the host. For example, the infrastructure construction in Myanmar must comply with Myanmar's laws and regulations for environmental protection in the early-stage demonstration, medium-term environmental assessment and later-stage inspection. In special cases, the problem can be resolved through bilateral or multilateral consultation. Table 1 gives part of the consultative results of memorandums of understanding and compliance with the Convention.

Table 1

Some Consultative Results

\begin{tabular}{ll}
\hline Consultative results & \multicolumn{1}{c}{ Involved parties } \\
\hline $\begin{array}{l}\text { China ASEAN Environmental protection cooperation strategy } \\
2016-2020\end{array}$ & $\begin{array}{l}\text { China, ASEAN (the Association of } \\
\text { Southeast Asian Nations) }\end{array}$ \\
\hline $\begin{array}{l}\text { Environmental protection cooperation in the Greater Mekong sub } \\
\text { region }\end{array}$ & $\begin{array}{l}\text { China, Kampuchea, Laos, Burma, } \\
\text { Thailand, Vietnam }\end{array}$ \\
\hline Espoo Convention & Russia, Kazakhstan, etc. \\
\hline $\begin{array}{l}\text { Convention on Access to Informatica, Public Participation in } \\
\text { Decision-making and Access to Justice in Environmental Matters }\end{array}$ & Russia, Kazakhstan, etc. \\
\hline $\begin{array}{l}\text { Cooperation agreement on environmental protection between China } \\
\text { and Tajikistan }\end{array}$ & China, Tajikistan \\
\hline $\begin{array}{l}\text { Cooperation agreement on environmental protection between China } \\
\text { and Uzbekistan }\end{array}$ & China, Uzbekistan \\
\hline
\end{tabular}




\section{Challenges in Natural Environmental}

On the whole, the natural environment of countries and regions along "the Belt and Road" is not friendly and the ecological environment is relatively fragile. For example, western regions of China, the Middle East and Central Asia generally face many problems such as complex geographical conditions, low precipitation, dry climate, degraded forests and grasses, increased soil erosion, severe desertification or rising sea levels (Khanji, 2017). Table 2 shows the natural condition data of some areas along "the Belt and Road" from 2014 to 2016 measured by the World Bank WDI database.

Table 2

Natural Condition Data in Some 'Belt and Road' Regions

\begin{tabular}{lcc}
\hline Regions & Desertification rate $(\%)$ & Area of woods $\left(\mathrm{km}^{2}\right)$ \\
\hline The world & 11.09 & - \\
The countries along the Belt and Road & 16.27 & - \\
China & 25.31 & $213.2 \times 10^{4}$ \\
Central Asia & 14.65 & $6.1 \times 10^{4}$ \\
North Africa & 67.80 & $34.7 \times 10^{4}$ \\
\hline
\end{tabular}

(average values of 2014 2016 years)

It can be seen from Table 2 that the average desertification rate of countries and regions along "the Belt and Road" is $16.27 \%$, and the desertification rate in North Africa is up to $67.80 \%$, which is much higher than the world average desertification rate at $11.09 \%$. At the same time, it can be seen from Table 2 that the forest coverage area of the countries and regions along "the Belt and Road" is relatively low, and the forest covered area of Central Asia is only 61,000 square kilometers.

\section{Challenges in Governance Capacity}

Most of the developing countries along "the Belt and Road" are still in the development mode of sacrificing the environment for economic growth. The funding and technology for environmental protection are insufficient and the environmental protection measures have not been strictly taking. Their governance capacity needs to be improved (Meir \& Alkon, 2018). At present, there are two more effective ways: one is to prevent the developed countries from transferring environmental pollution industries to developing countries through publicity and guidance and the other is to strengthen the environmental protection technology cooperation among countries and regions along the route to reduce the overall pollution stock.

\section{Situation Analysis of Short-Term Overseas Study Tour of College Students in Countries and Regions along "The Belt and Road"}

"The Belt and Road" strategy spans Asia, Europe and the African continent and there are more than 70 countries and regions along the route with rich and abundant higher education resources. With the increasing 
Zhang, Wang / "The Belt and Road" and Environmental Education for College Students before Overseas Study Tour、

demand for high-tech compound talents in the labor market and the growing problem of population aging, countries and regions along the route welcome international students, and they try to attract high-quality students by increasing the funding for higher education and introducing various measures. Meanwhile, they encourage short-term talent flow and exchange through reforming the teaching model (Liu, Liu \& $\mathrm{Hu}, 2016$ ).

\section{Developing Level of Higher Education in Countries and Regions along the Route}

According to the classification criteria for higher education proposed in literature (Trow, 2005), higher education is divided into universal education, popular education, and elite education according to the enrollment rate of higher education. The universal education refers to enrollment rate over 50\%; the popular education refers to the enrollment rate between $15 \%$ and $50 \%$; the elite education refers to the enrollment rate below $15 \%$. According to the data published by UNESCO (UNESCO, 2015), the education process in countries and regions along "the Belt and Road" can be classified, as shown in Table 3.

Table 3

Different Types of Education in the Countries Along the Belt and Road

\begin{tabular}{ll}
\hline Education types & \multicolumn{1}{c}{ The countries along the Belt and Road } \\
\hline Popular education & Germany, Singapore, France, Japan, Italy, Netherlands, etc. \\
Mass education & Vietnam, India, Egypt, Indonesia, Malaysia, etc. \\
Elite education & Kenya, Uzbekistan, Afghanistan, Turkmenistan, etc. \\
\hline
\end{tabular}

It can be seen from Table 3 that the countries where the higher education belongs to universal education are mostly developed countries, such as Germany and Singapore; countries where the higher education belongs to popular education are mostly middle-level developing countries, such as Vietnam and India; countries where the higher education belongs to elite education are mostly low-level developing countries such as Kenya and Uzbekistan. The higher the popularization degree of higher education, the higher the education level, the higher the educational investment and the stronger the bearing capacity of accepting students of this country. Correspondingly, the higher the popularization degree of higher education, the stronger the attraction as a shortterm overseas study destination.

\section{Situation Analysis of Short-Term Overseas Study Tour Education}

Short-term overseas study tour is one of the traditional ways of studying abroad. It emphasizes the completion of international experiential education in a short period of time, the purpose of which is to understand different cultures, develop international vision and promote communication (Philip, Liz \& Laura, 2009). The implementation of "the Belt and Road" strategy has enabled more and more college students to choose countries and regions along "the Belt and Road" as short-term overseas study destinations. The number of foreign students studying in the countries and regions along "the Belt and Road" is shown in Table 4.

It can be seen from Table 4 that the number of students for short-term overseas study tour is increasing year by year. At the same time, the proportion of countries and regions along "the Belt and Road" as destinations has also increased year by year. In $2017,64.3 \%$ of the 801,000 person-times of overseas study tour took the countries and regions along "the Belt and Road" as destinations. It can be seen that "the Belt and Road" strategy has enhanced the attention and enthusiasm of more and more young students. 
Table 4

Short Term Overseas Study Statistics

\begin{tabular}{lcc}
\hline Years & Total number (ten thousand) & Percentage of the countries along the Belt and Road \\
\hline 2014 & 15.4 & $33.9 \%$ \\
2015 & 47.3 & $38.4 \%$ \\
2016 & 73.9 & $57.1 \%$ \\
2017 & 80.1 & $64.3 \%$ \\
\hline
\end{tabular}

\section{Correlation Analysis of Environmental Education for College Students before Overseas Study Tour and "The Belt and Road"}

Through the above analysis of the short-term overseas study tour of college students and the challenge of environmental protection faced by countries along "the Belt and Road", it can be seen that education plays an obvious leading role in "the Belt and Road" strategy. The environmental education for college students before overseas study provides a new way to solve environmental problems. In addition to technological, capital, cultural and education exchanges, the international influence of the "green development concept" advocated by China is expanded through the environmental education before overseas study tour, which ensures the smooth implementation of "the Belt and Road" strategy. The environmental education before overseas study tour is expected to have short-term and long-term effects: the short-term effect refers to the protection of the environment in the personnel flow so as not to cause excessive human intervention and new damage to the fragile ecological environment in some areas; the long-term effect refers to the fact that the cultural and technological exchange enhances the mutual understanding among different countries the collaboration level between different entities and the ability to jointly address environmental protection issues. This study uses the empirical analysis method to investigate the short-term and long-term correlation between environmental education for college students before overseas study tour and "the Belt and Road" through questionnaires.

\section{Short-Term Correlation Analysis}

Through the questionnaire survey of students studying abroad and the statistical analysis of the survey results, the short-term correlation result of environmental education for college students before overseas study tour and "the Belt and Road" is obtained. The questionnaire includes objective questions and subjective questions. For example, the objective questions include "Do you know the environmental protection laws and regulations of the country of destination?", "Does China sign an environmental protection agreement/treaty/memorandum with the country of destination?", "Do you know the ecological environment status of the country of destination?" and "Whether environmental education before the overseas study tour has increased your awareness of environmental protection." The subjective questions include "What needs to be added in environmental education before the overseas study tour", and "What knowledge do you think is not necessary in environmental education before the overseas study tour'? Altogether 1000 questionnaires are issued about short-term correlation analysis and 957 valid questionnaires are collected. The statistical analysis of 957 valid questionnaires is performed according to the method introduced in literature (Lee, 2002) and the results show that in the short-term, college students can learn to master China's initiatives in promoting green 
Zhang, Wang / "The Belt and Road" and Environmental Education for College Students before Overseas Study Tour、

"the Belt and Road" construction and "the Belt and Road" ecological environmental protection cooperation. In this way, college students can understand the environmental protection laws and regulations, the status of natural ecological environment and the level of environmental governance capability of the country of destination and they can also raise their environmental awareness in a short period of time.

\section{Long-term Correlation Analysis}

Similarly, the long-term correlation between the environmental education for college students before overseas study tour and "the Belt and Road" is also obtained through the statistical analysis of questionnaires. The questionnaire also includes objective questions and subjective questions. For example, the objective questions include "Are you willing to pay attention to the environmental protection issues in the countries and regions along 'the Belt and Road' for a long time?", “Are you willing to engage in environmental protection work for a certain period of time", "Would you like to provide long-term environmental protection volunteer service" and "Whether the environmental education before overseas study tour will have a long-term impact on your environmental protection concept". The subjective questions include "he environmental education before overseas study tour has made you interested in what aspect of knowledge?", "You have formulated long-term plan in what aspects of the environmental protection issues" and "what do you think is the difficulty of environmental protection in the countries and regions along "the Belt and Road"'? 1000 questionnaires are issued for the long-term correlation analysis and 866 valid questionnaires are collected. According to the method described in literature (Lee, 2002), the analysis results show that the environmental education before overseas study tour can guide the students to pay attention to environmental protection issues after the study tour, which can have long-term impact on the environmental awareness of college students, their employment intention and their intention of long-term environmental protection volunteer service.

\section{Suggestions for Environmental Education Content}

Through the questionnaire survey of experts in environmental protection and education and the re-analysis of the questionnaire survey results of college students, the content of environmental education before overseas study tour is updated and improved. The improved environmental education content includes six aspects: one is the existing legal system of environmental protection in the countries along the route; the second is the environmental protection agreement signed by the countries along the route; the third is the ecological environment status of the country of destination; the fourth is the issues of environmental protection that should be noted by individuals; the fifth is the contribution of personal professional knowledge to environmental protection; the sixth is the investigation method of environmental protection issues. Certainly, when implementing specific education work, the specific educational content can be supplemented or deleted according to the educational years, educational background and differences in the country of destination. 


\section{Conclusion}

The purpose of the environmental education for college students before overseas study tour is to promote the smooth implementation of "the Belt and Road" strategy. Through the multi-faceted analysis of the challenges faced by countries along "the Belt and Road" in terms of environmental protection and the analysis of the distribution of educational resources in countries along "the Belt and Road" and the situation of shortterm overseas study tour of college students, this paper proposes to solve the environmental problems in the countries along the route with the help of the environmental education before overseas study tour, which provides a new way for the research of environmental protection. At the same time, it is found through questionnaire survey that there is both long-term and short-term correlation between the environmental education for college students before overseas study and "the Belt and Road" strategy. This kind of education has a positive impact on the smooth promotion of the "the Belt and Road" strategy. Through empirical analysis, this paper proposes suggestions for the setting of environmental education content and the targeted content setting can significantly improve the educational effect. In summary, the environmental education for college students before overseas study tour is of great practical significance for the smooth implementation of "the Belt and Road" strategy.

\section{References}

Bräutigam, D., \& Tang, X. (2014). “Going global in groups”: Structural transformation and China’s special economic zones overseas. World Development, 63, 78-91.

Lee, C. Y. (2002). Industry R\&D intensity distributions: regularities and underlying determinants. Journal of Evolutionary Economics, 12(3), 307-341. http://dx.doi. org/10.1007/s00191-002-0117-9

Li, M. Z. (2017). 'One Belt and One Road' construction and environmental protection along the line. Journal of Inner Mongolia University (Philosophy and Social Sciences), 49(1), 34-38.

Liu, Z. M., Liu, L., \& Hu, S. S. (2016). On the process of mass higher education of 73 countries along the 'Belt and Road' initiative regions. International and Comparative Education, 38(4), 1-8.

Trow, M. (2007). Reflections on the transition from elite to mass to universal access: Forms and phases of higher education in modern societies since WWII. In International handbook of higher education. Springer, Dordrecht. 243-280.

Meir, \& Alkon. (2018). Do special economic zones induce development spillovers? Evidence from India's states. World Development, 107(7), 396-409.

Philip, G. A., Liz, R., \& Laura, E. R. (2009). Trends in global higher education: tracking an academic revolution. The UNESCO 2009 World Conference on Higher Education, (7), 1 24.

El Khanji, S. (2017). An exploration of the interaction between socio-economic productivity and water withdrawal. Environment, development and sustainability, 19(2), 653-677. http://dx.doi. org/10.1007/s10668-016-9757-z

UNESCO. (2015). Gross enrollment ratio by level of education (1970 2014).

Wang, L. Z., \& Zhang, Y. J. (2016). Strategic positioning and governance system on environmental problems under the perspective of 'the Belt and Road Initiatives'. Chinese Journal of Environmental Management, 4, 60-64. 